\title{
Preparation and binding study of a complex made of DNA-treated single-walled carbon nanotubes and antibody for specific delivery of a "molecular heater" platform
}

\author{
This article was published in the following Dove Press journal: \\ International Journal of Nanomedicine \\ 7 August 2012 \\ Number of times this article has been viewed
}

\author{
Minoru Kawaguchi ${ }^{1,2}$ \\ Jun Yamazaki ${ }^{2,3}$ \\ Jun Ohno 2,4 \\ Tadao Fukushima ${ }^{2,5}$ \\ 'Department of Dental Engineering, \\ Biomaterials Section, Fukuoka Dental \\ College, Sawara-ku, Fukuoka; ${ }^{2} J a p a n$ \\ Science and Technology Agency, \\ Core Research of Evolutional Science \\ and Technology, Chiyoda-ku, Tokyo; \\ ${ }^{3}$ Department of Physiological Science \\ and Molecular Biology, Section of \\ Cellular and Molecular Regulation, \\ ${ }^{4}$ Department of Morphological \\ Biology, Pathology Section, ${ }^{5}$ Center \\ for Regenerative Medicine, Fukuoka \\ Dental College, Sawara-ku, Fukuoka, \\ Japan
}

\begin{abstract}
Carbon nanotubes have been explored as heat-delivery vehicles for thermal ablation of tumors. To use single-walled carbon nanotubes (SWNT) as a "molecular heater" for hyperthermia therapy in cancer, stable dispersibility and smart-delivery potential will be needed, as well as lack of toxicity. This paper reports the preparation of a model complex comprising DNA-treated SWNT and anti-human IgG antibody and the specific binding ability of this model complex with the targeted protein, ie, human IgG. Treatment with double-stranded DNA enabled stable dispersibility of a complex composed of SWNT and the antibody under physiological conditions. Quartz crystal microbalance results suggest that there was one immobilized IgG molecule to every 21,700 carbon atoms in the complex containing DNA-treated SWNT and the antibody. The DNA-SWNT antibody complex showed good selectivity for binding to the targeted protein. Binding analysis revealed that treatment with DNA did not interfere with binding affinity or capacity between the immobilized antibody and the targeted protein. The results of this study demonstrate that the DNA-SWNT antibody complex is a useful tool for use as a smart "molecular heater" platform applicable to various types of antibodies targeting a specific antigen.
\end{abstract}

Keywords: carbon nanotubes, DNA functionalization, complex, antibody, binding ability

\section{Introduction}

Carbon nanotubes have been intensively investigated for biological and biomedical applications. Carbon nanotubes release substantial vibrational energy after exposure to near-infrared radiation. This release of energy produces heating localized within a tissue, which can potentially be used for phototherapy in the treatment of cancer. $^{1-5}$

Our hypothesis was that single-walled carbon nanotubes (SWNT) could be used as an exothermic molecular device for hyperthermic cancer therapy. To achieve good performance for an SWNT-based molecular heating device, two main issues should be considered, ie, achieving stability and good dispersibility of SWNT in body fluids and selective attachment of the SWNT to targeted tumor cells. In a previous study, we prepared DNA-SWNT by treatment with double-stranded DNA. The DNA-SWNT was shown to improve the dispersibility of SWNT in vitro (culture medium) and in vivo (subcutaneous mouse tissue) significantly when compared with acid-treated SWNT. This result suggests that functionalization with DNA is an efficient approach to improve the dispersibility of SWNT in body fluids.
Correspondence: M Kawaguchi

Department of Dental Engineering, Biomaterials Section, Fukuoka Dental College, Sawara-ku, Fukuoka 8|4-0193, Japan

Tel $+8|9280| 04 \mid$ I

Fax $+8 \mid 928014909$

Email kawagum@college.fdcnet.ac.jp 
To achieve selective targeting of cells, conjugation of DNA-SWNT with certain ligands specifically recognizing tumor cells would be the most efficient approach. Targeting ligands, including folic acid, peptides, and antibodies, have been used for carbon nanotube-based drug delivery systems to develop a smart-delivery nanocarrier. ${ }^{7,8}$ Several researchers have studied specific antibodies attached to the side wall of the SWNT. Chakravarty et $\mathrm{al}^{9}$ prepared an anti-CD22-targeted SWNT construct and demonstrated its selective binding to tumor cells. The SWNT was solubilized by interaction with biotinylated poly(ethylene glycol) (PEG), and coupled with an antibody-avidin conjugate. McDevitt et $\mathrm{al}^{10}$ synthesized SWNT antibody constructs from covalently attached amino-terminated PEG and thiolated anti-CD 20 antibody and evaluated their specific ability to target a Daudi tumor cell line.

Covalent attachment of antibody directly to the side wall of SWNT is a very feasible procedure. However, this may cause structural changes in antibody molecules, which would alter their specific binding ability. How to design antibodies for attachment to SWNT may be a critical factor in binding of the SWNT antibody complex to targeted cells. Because DNA-SWNT was found to improve the dispersibility of SWNT significantly, ${ }^{6}$ a complex based on DNA-SWNT with an antibody attached is a potential model for a stable and smart exothermic device. However, the effect of DNA coating on the specific binding ability of the DNA-SWNT antibody complex to targeted cells is not clear.

The purpose of this study was to prepare a model complex composed of DNA-SWNT and an antibody, to clarify the relationship between them quantitatively, and to investigate the specificity, affinity, and capacity of antibody binding to the target protein. If the antibody shows strong and specific binding affinity to the targeted protein, even when immobilized on DNA-coated SWNT, the DNA-SWNT would be a suitable platform for a complex with antibodies. For this purpose, we designed a simple model made of DNA-SWNT and antibody raised against human IgG as a target protein. Using this system, key factors such as immobilization methods and the binding properties of antibodies can be evaluated. In this study, we prepared a DNA-SWNT antibody model complex using biotinylated $\mathrm{IgG}$ and an intermediate complex (streptavidin covalently bound to DNA-SWNT), estimated the binding ratio of SWNT and antibody, and evaluated the effect of DNA coating on the specificity, affinity, and capacity of binding of the DNA-SWNT antibody complex to the targeted protein.

\section{Materials and methods Preparation of DNA-SWNT}

Preparation of the acid-treated SWNT (average diameter $1 \mathrm{~nm}$, average length $800 \mathrm{~nm}, \mathrm{CG100}$, South West Nanotechnology, Norman, OK) was carried out according to a method described previously. ${ }^{6}$ Acid-treated SWNT $10 \mathrm{mg}$ and DNA $100 \mathrm{mg}$ (derived from salmon testis, average $300 \mathrm{bp}$, MaruhaNichiro Holdings, Tokyo, Japan) were sonicated (90 W, type 1510, Branson, Danbury, CT) in $10 \mathrm{~mL}$ of deionized water for one hour. The resulting aqueous solution of DNASWNT (1 mg/mL, based on SWNT amount) was subjected to preparation as an antibody complex.

\section{Preparation of DNA-SWNT antibody complex}

The DNA-SWNT solution (containing $10 \mathrm{mg}$ of SWNT) was supplemented with $2 \mathrm{~mL}$ of $\mathrm{N}$-hydroxysuccinimide $(0.87 \mathrm{M}$, Nacalai Tesque, Kyoto, Japan) and $2 \mathrm{~mL}$ of 1-ethyl-3(3dimethylaminopropyl) carbodiimide hydrochloride (EDC, $0.52 \mathrm{M}$, Wako Chemicals, Osaka, Japan), and gently stirred at room temperature. After mixing for 3 hours, $2 \mathrm{mg}$ of streptavidin (Sigma-Aldrich, St Louis, MO) was added to the solution and stirred for 3 hours at $5^{\circ} \mathrm{C}$, and then $1 \mathrm{~mL}$ of 2-aminoethanol solution ( $5 \mathrm{mM}$, Nacalai Tesque) was added to mask the unreacted carboxyl group on the DNA-SWNT, with stirring for one further hour at $5^{\circ} \mathrm{C}$. The resulting solution was filtered using a polytetrafluoroethylene membrane $(0.2 \mu \mathrm{m}$ pore size) to collect the DNA-SWNT streptavidin complex.

The filtered DNA-SWNT streptavidin complex was adjusted to a concentration of $1 \mathrm{mg} / \mathrm{mL}$ (based on amount of SWNT) in phosphate-buffered solution (containing $0.01 \%$ n-dodecyl- $\beta$-D-maltoside, DDM, Dojindo, Kumamoto, Japan) using ultraviolet absorbance. The biotinylated antihuman IgG $(200 \mu \mathrm{g}$, generated in a donkey, having minimal cross-reactivity with other species, Rockland Immunochemicals, Gilbertsville, PA) was added to $2 \mathrm{~mL}$ of the DNA-SWNT streptavidin solution and gently stirred for 2 hours at $5^{\circ} \mathrm{C}$. After filtration using a polytetrafluoroethylene membrane ( $0.2 \mu \mathrm{m}$ pore size), the DNA-SWNT antibody complex was dispersed in phosphate-buffered solution containing DDM (final concentration $500 \mathrm{mg} / \mathrm{mL}$ ). A schematic diagram for preparation of the DNA-SWNT antibody complex is shown in Figure 1.

\section{Preparation of SWNT antibody complex}

The SWNT antibody complex was prepared from acid-treated SWNT. The preparation was carried out using the same 
DNA-SWNT
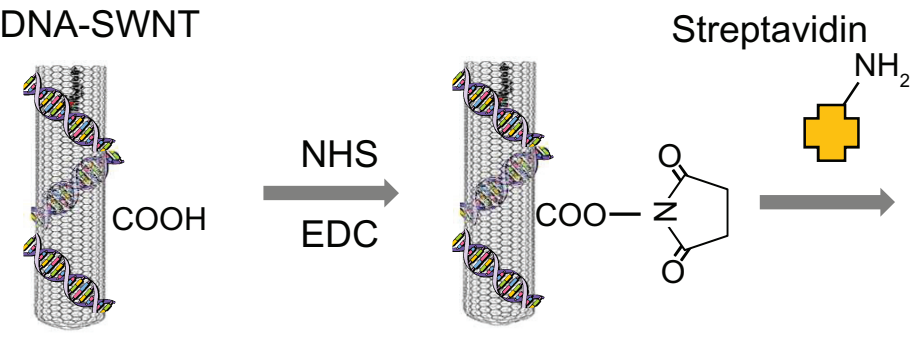

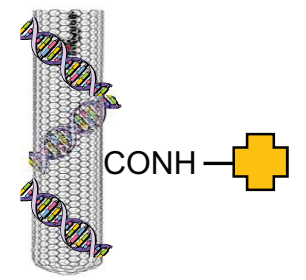

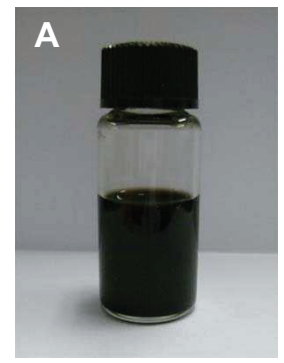

DNA-SWNT-Ab complex

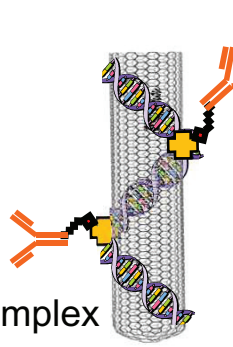

Figure I Procedure for immobilization of streptavidin on the DNA-SWNT surface, and binding of biotinylated IgG to immobilized streptavidin to prepare the DNA-SWNT antibody complex. (A) Suspension of DNA-SWNT antibody complex.

Abbreviations: Ab, antibody; SWNT, single-walled carbon nanotubes; NHS, N-hydroxysuccinimide; EDC, I-ethyl-3(3-dimethylaminopropyl) carbodiimide hydrochloride.

procedure as described for preparation of the DNA-SWNT antibody complex.

\section{Measurement of binding ratio using quartz crystal microbalance}

A gold-coated quartz sensor with a fundamental frequency of $27 \mathrm{mHz}$ (Affinix C4, Initium, Chigasaki, Japan) was used. For the quartz crystal microbalance (QCM) system used in this study, $1 \mathrm{~Hz}$ of frequency decrease was calibrated as an increase of 0.03 ng. ${ }^{11,12} \mathrm{~A}$ mixture of the DNA-SWNT, $\mathrm{N}$-hydroxysuccinimide, and water-soluble carbodiimide was prepared according to the method described earlier and stirred for 3 hours. A $2 \mu \mathrm{L}$ droplet of this solution was carefully placed on the sensor surface and dried for one hour. After rinsing twice with deionized water to remove unbound DNA-SWNT, it was dried again for 30 minutes. The amount of coated DNA-SWNT was determined from the change in frequency before and after coating.

The DNA-SWNT-coated sensor was exposed to $500 \mu \mathrm{L}$ of HEPES buffer (containing $0.1 \mathrm{M} \mathrm{NaCl}$ and $0.01 \%$ DDM). When the frequency of the sensor had stabilized, the streptavidin solution was injected (final concentration $0.1 \mathrm{mg} / \mathrm{mL}$ ) and frequency was monitored as a function of time. The amount of streptavidin bound to DNA-SWNT was determined from this frequency shift. The sensor surface was then exposed to $5 \mathrm{mM}$ 2-aminoethanol solution for one hour to mask the unreacted carboxyl groups of the DNA-SWNT. The sensor was exposed to $500 \mu \mathrm{L}$ of TE buffer containing $0.15 \mathrm{M} \mathrm{NaCl}$, and the biotinylated anti-human IgG was injected (final concentration $50 \mu \mathrm{g} / \mathrm{mL}$ ). The amount of IgG bound to the DNA-SWNT streptavidin complex was determined from the frequency shift. The amounts of streptavidin and IgG bound to the acidtreated SWNT were determined in the same manner as for measurement of the DNA-SWNT antibody.

\section{Detection of binding of SWNT antibody complex to target protein}

Ninety-six-well polystyrene microplates (BD Biosciences, Franklin Lakes, NJ) were incubated overnight at $4{ }^{\circ} \mathrm{C}$ with $100 \mu \mathrm{L}$ of $10 \mu \mathrm{g} / \mathrm{mL}$ human IgG or rabbit IgG (ChromPure, whole molecule, Jackson ImmunoResearch Laboratories Inc, West Grove, PA). After washing with phosphate-buffered solution, the wells were blocked with $3 \%$ bovine serum albumin dissolved in phosphate-buffered solution containing $0.01 \%$ DDM for 30 minutes. The solution was then replaced with different concentrations of either biotinylated antihuman IgG antibodies or a complex (DNA-SWNT antibody or SWNT antibody), each of which was dissolved in phosphate-buffered solution containing $1 \%$ bovine serum albumin and $0.01 \%$ DDM. DNA $(1 \mathrm{mg} / \mathrm{mL})$ was also included in the incubation mixture for experiments using the complex or $\operatorname{IgG}$ alone. After incubation at $37^{\circ} \mathrm{C}$ for $60-90$ minutes, the wells were washed three times with $0.05 \%$ Tween 20 containing phosphate-buffered solution.

To detect the complex, the wells were treated at room temperature for 1.0-1.5 hours with mouse monoclonal anti-streptavidin 
antibody (1000×, S3E11, Pierce Biotechnology, Rockford, IL) and then goat monoclonal anti-mouse IgG antibody (light chain-specific, cross-reacted minimally with other species) conjugated with horseradish peroxidase $(20,000 \times$, Jackson ImmunoResearch Laboratories Inc), both of which were dissolved in phosphate-buffered solution containing $1 \%$ bovine serum albumin and $0.01 \%$ DDM. The wells were washed thoroughly with $0.05 \%$ Tween 20 containing phosphatebuffered solution after each treatment. To detect the biotinylated antibodies without SWNT, streptavidin $(1 \mu \mathrm{g} / \mathrm{mL})$ was first bound to the biotin side chain, and then incubated with the antibodies in the above order. Prior to horseradish peroxidase assay, absorbance at $450 \mathrm{~nm}$ was measured as a blank $\left(\mathrm{Abs}_{\text {Blank }}\right)$. Thereafter, horseradish peroxidase assay was performed using $3,3^{\prime}, 5,5^{\prime}$-tetramethylbenzidine (TMB) as a substrate and an excess amount of $\mathrm{H}_{2} \mathrm{O}_{2}$ (TMB substrate reagent set, $\mathrm{BD}$ Falcon $\left.{ }^{\circledR}\right)$. The reagents were incubated in the wells for $0-15$ minutes, followed by stopping the reaction with $1 \mathrm{M}$ phosphoric acid. Absorbance $\left(\mathrm{Abs}_{\mathrm{TMB}}\right)$ of the reaction mixture at $450 \mathrm{~nm}$ was measured, which was dependent on the production of yellow compound, ie, oxidized TMB (diimine form of TMB), under acidic conditions. The difference in value $\left(\mathrm{Abs}_{\mathrm{TMB}}-\mathrm{Abs}_{\mathrm{Blank}}\right)$ was calculated to obtain the amount of oxidized TMB. The initial production rate of oxidized TMB was calculated on the basis of the Lambert-Beer Law, and the molar extinction coefficient at $450 \mathrm{~nm}\left(\varepsilon_{450}\right)$ of oxidized TMB was reported to be $5.9 \times 10^{4} \mathrm{M}^{-1} \mathrm{~cm}^{-1} .{ }^{13}$

\section{Statistics}

All values are presented as the mean \pm standard error of the mean (n, number of observations). Statistical analysis was performed using the unpaired $t$-test. A $P$ value less than 0.05 was considered to be statistically significant.

\section{Results \\ Preparation of DNA-SWNT antibody and SWNT antibody complexes}

The DNA-SWNT antibody complex suspension was stable in water and phosphate-buffered solution for at least two weeks at $4{ }^{\circ} \mathrm{C}$ without aggregation or precipitation (Figure 1A). However, the SWNT antibody suspension (without DNA) formed a small amount of precipitate after being stored for two weeks at $4^{\circ} \mathrm{C}$.

\section{Measurement of binding ratio of DNA- SWNT antibody complex using QCM}

The amounts of immobilized SWNT and DNA-SWNT on the QCM sensor surface were $146.3 \pm 14.2 \mathrm{ng}$ and $147.3 \pm 14.0 \mathrm{ng}$, respectively $(n=7)$. The curve in Figure 2A shows typical frequency changes as a function of time, indicating binding of streptavidin to the DNA-SWNT-immobilized QCM. Addition of streptavidin decreased the frequency (with an increase in mass) in several minutes. The curve in Figure 2B shows the typical frequency change when anti-human $\operatorname{IgG}$ antibody was applied to the sensor on which the DNASWNT-streptavidin had been immobilized. These consecutive changes in frequency represent the amounts of streptavidin bound to DNA-SWNT and the amounts of IgG then bound to DNA-SWNT-streptavidin. However, the molar ratio for binding of SWNT, streptavidin, and IgG could not be calculated accurately because the molecular weight of SWNT of variable length cannot be estimated. Therefore, we calculated the number of carbon atoms in SWNT immobilized on the QCM sensor using Avogadro's constant (Table 1). The calculated numbers for carbon atoms were $7.30 \times 10^{15}$ and $7.35 \times 10^{15}$ for SWNT and DNA-SWNT, respectively. On the basis of the molecular weights of streptavidin $(60,000)$ and $\operatorname{IgG}(150,000)$,
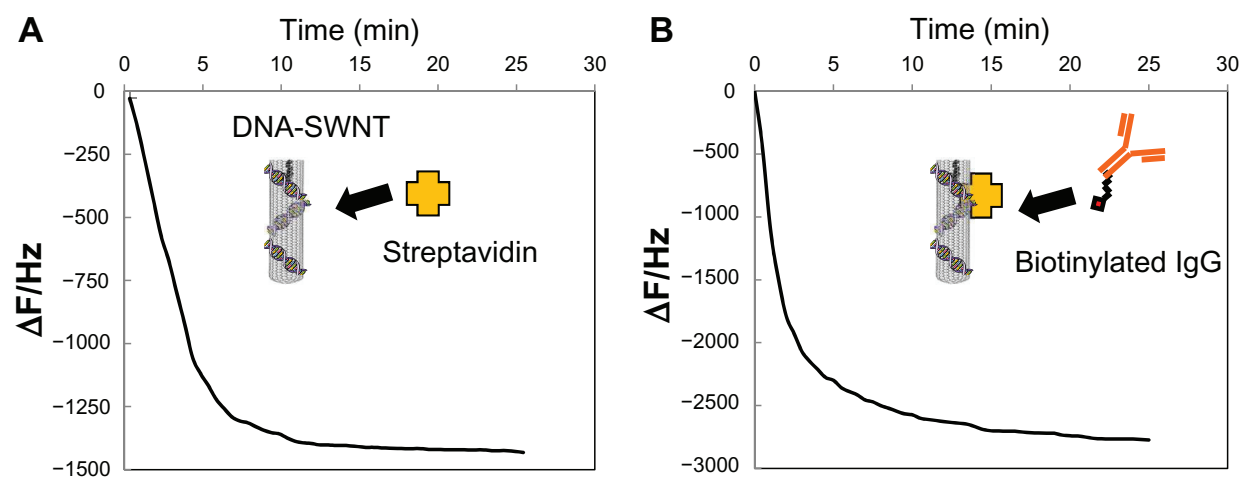

Figure 2 Typical frequency changes for (A) streptavidin immobilized to DNA-SWNT according to the quartz crystal microbalance sensor, and (B) binding of biotinylated anti-human $\lg G$ to the streptavidin-immobilized DNA-SWNT according to the quartz crystal microbalance sensor.

Abbreviation: SWNT, single-walled carbon nanotubes. 
Table I Binding ratio of the SWNT antibody and the DNA-SWNT antibody complexes calculated from quartz crystal microbalance data

\begin{tabular}{|c|c|c|c|}
\hline & $\begin{array}{l}\text { SWNT } \\
\text { (carbon atoms) }\end{array}$ & SA molecules & IgG molecules \\
\hline \multicolumn{4}{|c|}{ SWNT-Ab complex } \\
\hline Amount (ng) & $7.30(0.7 I) \times 10^{15}$ & $3.81(0.25) \times 10^{11}$ & $3.43(0.26) \times 10^{11}$ \\
\hline Ratio & $1.92 \times 10^{4}$ & 1 & 0.91 \\
\hline \multicolumn{4}{|c|}{ DNA-SWNT-Ab complex } \\
\hline Amount (ng) & $7.35(0.70) \times 10^{15}$ & $3.86(0.29) \times 10^{11}$ & $3.34(0.28) \times 10^{11}$ \\
\hline Ratio & $1.89 \times 10^{4}$ & 1 & 0.87 \\
\hline
\end{tabular}

Notes: Carbon atom numbers were calculated from Avogadro's constant. The binding ratio is presented with the number of binding SA molecules assumed as I. Values in parentheses denote standard deviation $(n=7)$.

Abbreviations: SA, streptavidin; Ab, antibody; SWNT, single-walled carbon nanotubes.

as well as the QCM results, the binding ratio (carbon atoms of SWNT to molecules of streptavidin to molecules of antibody) for the DNA-SWNT antibody complex was comparable with that for the SWNT antibody complex.

\section{Selective binding of DNA-SWNT antibody complex to target protein}

To examine the specificity of binding of the SWNT antibody complex to the target protein, we chose human IgG and rabbit $\mathrm{IgG}$ as target molecules and adhered each of these two to the bottom of the wells. Here, we produced an SWNT antibody complex using IgG generated in a donkey against human IgG. Figure 3A shows that the SWNT antibody complex (without DNA) binds selectively to human IgG (the target), but not rabbit $\mathrm{IgG}$, up to a concentration of $30 \mu \mathrm{g} / \mathrm{mL}$. This indicates that even a complex with a bulky structure did not alter the specificity of binding to the target molecule. When the DNA-SWNT antibody complex was used, specificity of binding was retained (Figure 3B), confirming that treatment with DNA is an effective method of increasing dispersibility without affecting the binding selectivity of $\mathrm{IgG}$.

A

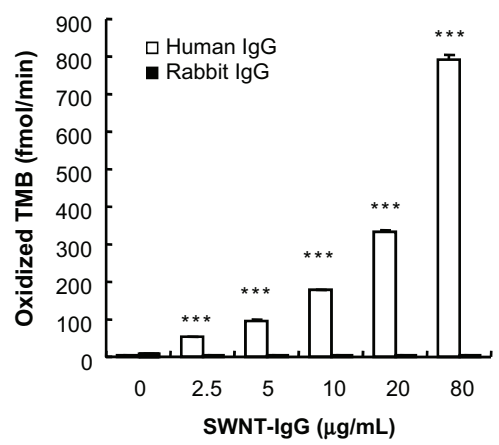

Binding affinity and capacity of DNASWNT antibody complex to target molecule

To quantify the binding ability of the SWNT antibody complex and compare several binding parameters under different conditions, the binding kinetics of the SWNT antibody (antihuman IgG antibody) complex to its target molecule were examined. Figure 4 shows typical data for binding between the SWNT antibody complex and the target molecule in the absence of DNA.

As shown in Figure 4A, the greater the concentration of the complex that was incubated, the higher the rate of oxidized TMB production that was obtained, suggesting concentration-dependent binding of the complex to its target molecule. The saturation curve obtained as described above appeared to be distorted at higher concentrations. A Lineweaver-Burk plot of the data gave an almost straight line, although it had a nonlinear portion at the two lowest 1/ [SWCT] values (Figure 4B). After omitting these values, the affinity constant $\left(\mathrm{K}_{\mathrm{m}, \mathrm{SWNT}}\right)$ and maximum reaction $\left(\mathrm{V}_{\max , \mathrm{SWNT}}\right)$ were estimated (Table 2). A Hill plot showed a straight

B

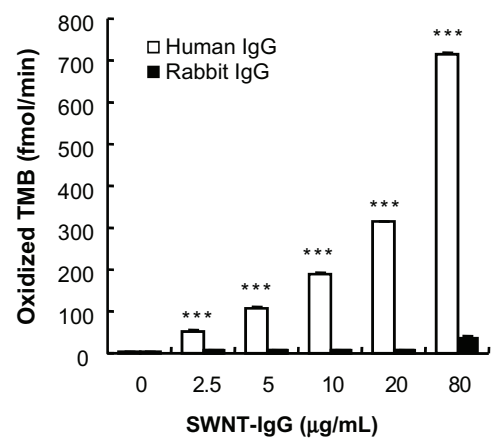

Figure 3 Selective binding of the SWNT antibody complex to target protein in the presence or absence of DNA. Either human IgG or rabbit IgG was adhered to the bottom of a microplate well. Initial rates of oxidized TMB production are plotted against the concentration of the SWNT antibody complex. (A) SWNT was not treated with DNA. (B) SWNT was treated with DNA, and the buffer contained I $\mathrm{mg} / \mathrm{mL}$ DNA.

Note: $* * * P<0.01$, compared with the corresponding value for rabbit lgG as the target protein $(n=4)$.

Abbreviations: TMB, 3,3',5,5'-tetramethylbenzidine; SWNT, single-walled carbon nanotubes. 
A
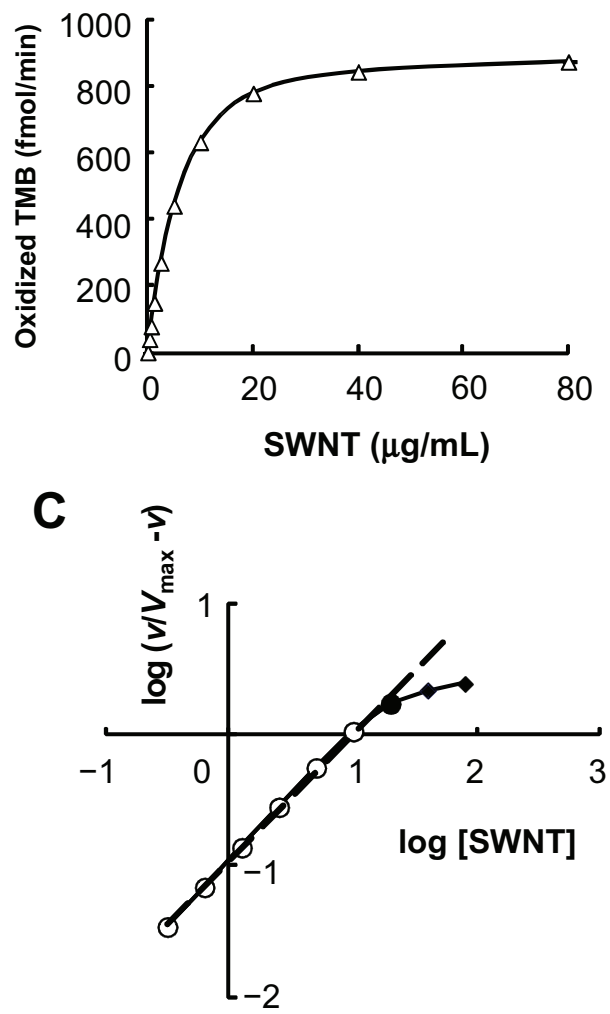

B

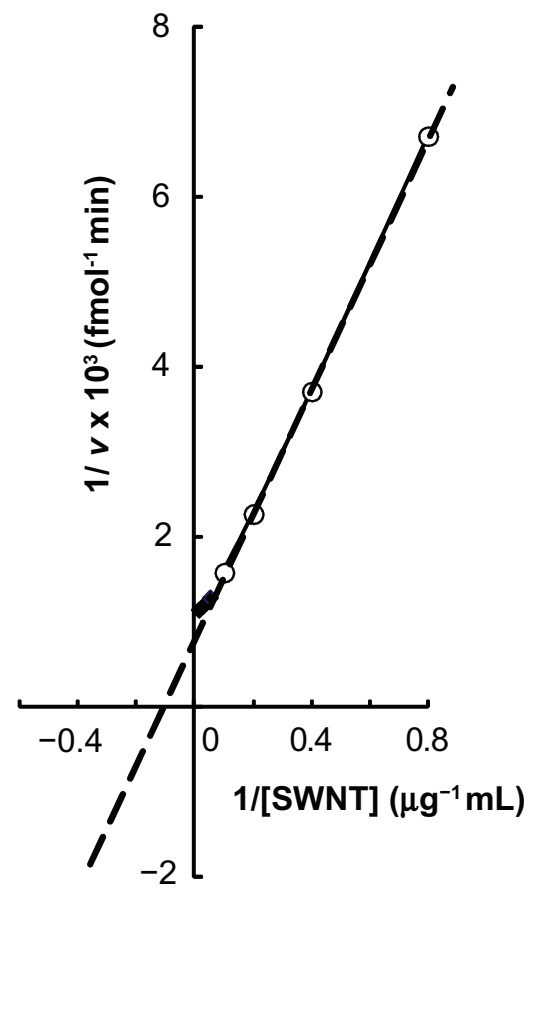

Figure 4 Binding of the SWNT antibody complex to its specific target. (A) Typical saturation curve. (B) Lineweaver-Burk plots. The data derived from the saturation curve were fitted to the dashed line (see text). The line represents $\mathrm{I} / \mathrm{V}_{\max }$ (obtained from ordinate intercept) and $\mathrm{I} / \mathrm{K}_{\mathrm{m}}$ (obtained from abscissa intercept). I/v $=0.007373$ $(\mathrm{I} /[\mathrm{SWNT}])+0.0008 \mathrm{I} 2, \mathrm{R}^{2}=0.999 . \mathrm{V}_{\text {max }, \mathrm{SWNT}}=123 \mathrm{I}, \mathrm{K}_{\mathrm{m}, \mathrm{SWNT}}=9.09(\mu \mathrm{g} / \mathrm{mL})$. (C) Hill plots. Slope of the line represents $n_{H}=0.959$.

Abbreviations: TMB, 3,3',5,5'-tetramethylbenzidine; SWNT, single-walled carbon nanotubes.

line, aside from the two highest values of $\log [\mathrm{SWNT}]$ (Figure 4C). The estimated Hill coefficient $\left(n_{\mathrm{H}}\right)$ was close to unity, indicating that the reaction obeys the MichaelisMenten equation and occurs between the SWNT antibody complex and the target molecule.

Figure 5 shows typical data for binding between $\mathrm{IgG}$ and its target in the absence of DNA. Figure 5A shows that the higher the concentration of IgG incubated, the higher the rate of oxidized TMB obtained. Figure 5B and 5C shows the Lineweaver-Burk and Hill plots. After omitting the data for the two highest concentrations of IgG, several parameters $\left(\mathrm{K}_{\mathrm{m}, \mathrm{IgG}}, \mathrm{V}_{\mathrm{max}, \mathrm{IgG}}\right.$, and $\left.n_{\mathrm{H}}\right)$ were estimated (Table 2). The $n_{\mathrm{H}}$ value was close to unity, indicating that the reaction also obeys the Michaelis-Menten equation in the absence of DNA.

Because the $\mathrm{V}_{\text {max }}$ values varied between tests, we performed a pair of assays for the SWNT antibody complex and for $\mathrm{IgG}$ alone in each set of experiments, and the relative $\mathrm{V}_{\text {max }}$ $\left(\mathrm{V}_{\text {max }, \mathrm{SWNT}} / \mathrm{V}_{\text {max,IgG }}\right)$ for the SWNT antibody complex to that for IgG itself was estimated. The relative $\mathrm{V}_{\text {max,SwNT }}$ was close to unity, suggesting that even a complex with a bulky structure did not change the binding capacity (Table 2).

According to the QCM results and the presumed molecular weight of SWNT, the $\mathrm{K}_{\mathrm{m}}$ value based on the concentration of $\operatorname{IgG}\left(\mathrm{K}_{\mathrm{m}, \mathrm{IgG}(\mathrm{SWNT})}\right)$ was calculated to be

Table 2 Binding affinity and capacity of SWNT-Ab and lgG itself to the target molecule in the absence of DNA

\begin{tabular}{|c|c|c|c|c|c|c|}
\hline & $n_{H}$ & $\begin{array}{l}K_{m, S W N T}(\mu g / m L) \\
\text { or } K_{m, I g G}(n g / m L)\end{array}$ & $\begin{array}{l}K_{m, \operatorname{lgG}(\mathrm{SWNT})} \\
\text { or } \mathrm{K}_{\mathrm{m}, \mathrm{lgG}}(\mathrm{mol} / \mathrm{L})\end{array}$ & $\begin{array}{l}\text { pK }_{m, \operatorname{lgG}(S W N T)} \\
\text { or } \mathbf{p K}_{\mathrm{m}, \mathrm{lgG}}\end{array}$ & $\begin{array}{l}\mathbf{V}_{\text {max,SWNT }} \\
\text { or } V_{\text {max,lgG }}(\mathrm{fmol} / \mathrm{min})\end{array}$ & $\mathbf{V}_{\text {max }, \text { SWNT }} / \mathbf{V}_{\max , \mathrm{Ig} G}$ \\
\hline SWNT-Ab & $0.99 \pm 0.001$ & $9.95 \pm 1.47$ & $(3.90 \pm 0.58) \times 10^{-8}$ & $7.4 \mathrm{I} \pm 0.06^{*}$ & $1255 \pm 126$ & $0.97 \pm 0.04$ \\
\hline $\lg G$ & $0.99 \pm 0.001$ & $54.7 \pm 3.1$ & $(3.65 \pm 0.20) \times 10^{-10}$ & $9.44 \pm 0.02$ & $1302 \pm 132$ & I \\
\hline
\end{tabular}

Notes: The $\mathrm{K}_{\mathrm{m}}$ values based on the concentration of $\operatorname{lgG}\left(\mathrm{K}_{\mathrm{m} \cdot \mathrm{g} G(\mathrm{SWNT})}\right)$ were calculated according to Lineweaver-Burk plots and quartz crystal microbalance data. The $\mathrm{V}_{\text {max }}$ for

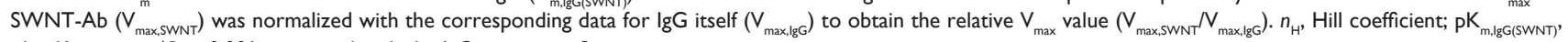
$-\log \mathrm{K}_{\mathrm{m}, \mathrm{gGG}(\mathrm{SWNT})} * \mathrm{P}<0.001$ compared with the $\lg \mathrm{G}$ group, $\mathrm{n}=3$.

Abbreviations: Ab, antibody; SWNT, single-walled carbon nanotubes. 
A

\section{ํㅗㄹ}
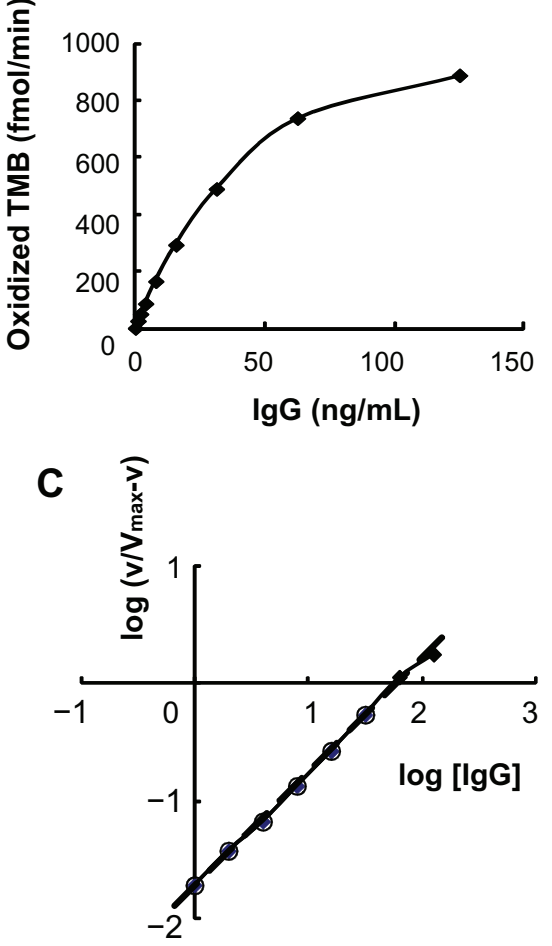

B

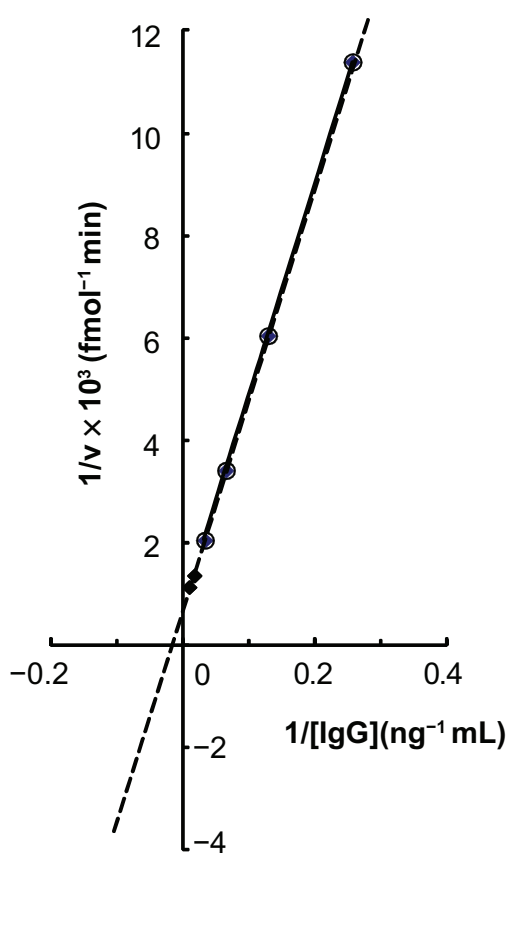

Figure 5 Binding of IgG to its specific target. (A) Typical saturation curve. (B) Lineweaver-Burk plots. The data derived from the saturation curve were fitted to the dashed line (see text). The line represents $\mathrm{I} / \mathrm{V}_{\max }$ (obtained from ordinate intercept) and $\mathrm{I} / \mathrm{K}_{\mathrm{m}}$ (obtained from abscissa intercept). I/v=0.04I700 $(\mathrm{I} /[\mathrm{IgG}])+0.0007 \mathrm{I} / \mathrm{g}, \mathrm{R}^{2}=0.999$. $V_{\text {max,lgG }}=1391, K_{m, l g G}=58.0(\mathrm{ng} / \mathrm{mL})$. (C) Hill plots. Slope of the line represents $n_{H}=0.957$.

Abbreviation: TMB, 3,3',5,5' -tetramethylbenzidine.

$(3.78 \pm 0.56) \times 10^{-8} \mathrm{M}$, which was 100 -fold higher than that of $\mathrm{K}_{\mathrm{m}, \mathrm{IgG}}\left[(3.65 \pm 0.20) \times 10^{-10} \mathrm{M}\right]$ (Table 2). Statistical analysis revealed that the $\mathrm{pK}_{\mathrm{m}, \mathrm{IgG}(\mathrm{SWNT})}$ value was significantly smaller than the $\mathrm{pK}_{\mathrm{m}, \mathrm{IgG}}$ value. This result suggests that the streptavidin-SWNT structure greatly attenuated the binding affinity of $\mathrm{IgG}$ to the target molecule.

Next, we tested the binding affinity and capacity of the DNA-SWNT antibody complex and IgG itself in the presence of DNA (1 mg/mL, Table 3). After omitting the plots at the two highest concentrations of the SWNT antibody complex and IgG, several parameters, ie, $\mathrm{K}_{\mathrm{m}, \mathrm{IgG}}, \mathrm{V}_{\mathrm{max}, \mathrm{IgG}}$, and $n_{\mathrm{H}}$, were calculated from the Lineweaver-Burk and Hill plots on the basis of the saturation curve (data not shown). A two-molecule reaction appeared to take place, namely between the DNASWNT-Ab complex and the target molecule. According to the relative $\mathrm{V}_{\max }\left(\mathrm{V}_{\max , \mathrm{SWNT}} / \mathrm{V}_{\max , \mathrm{IgG}}\right), \mathrm{K}_{\mathrm{m}, \mathrm{IgG}(\mathrm{SWNT})}$, and $\mathrm{K}_{\mathrm{m}, \mathrm{IgG}}$ values, the bulky structure of the DNA-SWNT antibody complex did not alter the binding capacity $\left(\mathrm{V}_{\max }\right)$, although it greatly attenuated the binding affinity of IgG to the target molecule because the $\mathrm{pK}_{\mathrm{m}, \mathrm{IgG}(\mathrm{SWNT})}$ value was significantly smaller than the $\mathrm{pK}_{\mathrm{m}, \mathrm{ggG}}$ value.

Comparison of the kinetic parameters for $\mathrm{IgG}$ in the presence or absence of DNA shows that an increase in dispersibility by DNA did not change the binding affinity or capacity of the SWNT antibody complex or for IgG (Tables 2 and 3).

Table 3 Binding affinity and capacity of DNA-treated SWNT-Ab and IgG itself to the target molecule in the presence of DNA

\begin{tabular}{|c|c|c|c|c|c|c|}
\hline & $n_{H}$ & $\begin{array}{l}K_{m, s W N T}(\mu g / m L) \\
\text { or } K_{m, l g G}(n g / m L)\end{array}$ & $\begin{array}{l}K_{m, \operatorname{lgG}(\mathrm{SWNT})} \\
\text { or } K_{\mathrm{m}, \mathrm{lgG}}(\mathrm{mol} / \mathrm{L})\end{array}$ & $\begin{array}{l}\text { pK }_{m, \operatorname{lgG}(S W N T)} \\
\text { or pK }{ }_{m, \operatorname{lgG}}\end{array}$ & $\begin{array}{l}V_{\text {max,SWNT }} \\
\text { or } V_{\text {max,IgG }}(\mathrm{fmol} / \mathrm{min})\end{array}$ & $\mathbf{V}_{\max , \mathbf{S W N T}} / \mathbf{V}_{\max , \lg G}$ \\
\hline $\begin{array}{l}\text { DNA- } \\
\text { SWNT-Ab }\end{array}$ & $0.99 \pm 0.001$ & $6.23 \pm 0.48$ & $(2.38 \pm 0.19) \times 10^{-8}$ & $7.63 \pm 0.03^{*}$ & $1355 \pm 94$ & $1.04 \pm 0.05$ \\
\hline $\lg G$ & $0.99 \pm 0.001$ & $57.2 \pm 4.5$ & $(3.81 \pm 0.30) \times 10^{-10}$ & $9.42 \pm 0.03$ & $1307 \pm 123$ & I \\
\hline
\end{tabular}

Notes: The $\mathrm{K}_{\mathrm{m}}$ values based on the concentration of the $\operatorname{lgG}\left(\mathrm{K}_{\mathrm{m}, \mathrm{gG}(\mathrm{SWNT})}\right)$ were calculated according to the Lineweaver-Burk plots and quartz crystal microbalance data.

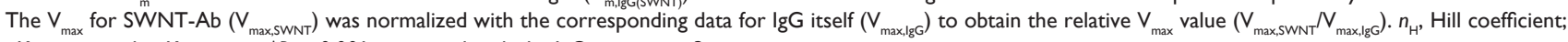
$\mathrm{PK}_{\mathrm{m}, \mathrm{lg} G(\mathrm{SWNT})},-\log \mathrm{K}_{\mathrm{m}, \mathrm{lgG}(\mathrm{SWNT})} * \mathrm{P}<0.001$ compared with the $\lg \mathrm{G}$ group, $\mathrm{n}=3$.

Abbreviations: $A b$, antibody; SWNT, single-walled carbon nanotubes. 


\section{Discussion}

In this report, we describe a targeted carbon nanotube system using a DNA-SWNT antibody complex to create soluble and stable SWNT that retains specificity for binding to the target protein under physiological conditions. For preparing the model DNA-SWNT antibody complex system, we introduced carboxylic acid groups onto the SWNT surface as attachment sites. The carboxylic acid groups were introduced onto the DNA-SWNT by acid treatment. During this process, carboxylic groups were formed at the ends of the tubes, and were used as conjugation sites to link other ligands to the SWNT surface. ${ }^{14,15}$ Streptavidin was then attached covalently onto the acid-treated SWNT via an N-hydroxysuccinimide and EDC coupling reaction to yield stable amide linkages. Subsequently, biotinylated IgG was allowed to bind specifically to the DNA-SWNT-streptavidin. Using this concept, various carbon nanotube systems could be designed using specific biotinylated antibodies corresponding to the targeted proteins. ${ }^{16}$

The streptavidin-biotin complex shows the highestaffinity noncovalent interaction (binding constant, $10^{-15} \mathrm{M}$ ). ${ }^{17}$ This coupling system is frequently used in biotechnology because of its high affinity constant and stability. The QCM results in this study indicate that approximately one biotinylated IgG molecule bound to one streptavidin molecule immobilized on the SWNT. Although streptavidin has four sites for biotin recognition, three sites were reported not to contribute to further biotin recognition. ${ }^{18} \mathrm{~A}$ possible explanation for this is steric hindrance due to the relatively large size of IgG and streptavidin molecules. The relatively large streptavidin molecule $(5.4 \times 5.8 \times 4.8 \mathrm{~nm})^{19}$ was immobilized on the side wall of the SWNT via a covalent bond, which may have caused structural deformation of the streptavidin molecule. A similar result was reported for gelatin nanoparticles attached to antibodies by the avidin-biotin complex (about 2.4 of the four biotin binding sites in the avidin molecule were available for complexation with biotin). ${ }^{20}$ Furthermore, segmental mobility of biotinylated IgG would affect the binding efficiency. The biotinylated IgG used in this study for the model complex system has a spacer arm $1.35 \mathrm{~nm}$ in length between the biotinyl group and the IgG molecule. A longer spacer arm length would confer a more flexible nature to the biotinylated IgG. There is a possibility that the spacer arm length between the biotinyl group and the $\mathrm{IgG}$ molecules is a key factor for binding of the biotinylated IgG molecule to the immobilized streptavidin molecule on the SWNT.

DNA was used as an effective solubilization substance to modify SWNT. ${ }^{21}$ In a previous study, ${ }^{6}$ we found that
DNA functionalization was an effective method to improve the stability and solubility of acid-treated SWNT in culture medium, although the mechanism of interaction between anionic-charged DNA and acid-treated SWNT was not clear. Nakashima et $\mathrm{al}^{22}$ suggested that $\pi-\pi$ interaction between the side wall of the SWNT and the nucleic acid bases of DNA with a partially deformed structure generated by sonication is an important factor for solubilization of SWNT. Zheng et $\mathrm{al}^{23}$ indicated that, for the single-stranded molecular CNT-DNA model interaction, $\pi-\pi$ stacking interaction forms a helical wrapping on the CNT surface. However, the DNA molecules coated to the acid-treated SWNT surface could be a cause for concern in terms of affecting the specific binding affinity of the DNA-SWNT antibody complex to the targeted protein. A DNA-SWNT antibody complex suspension was stable for at least two weeks, so antibody attachment did not affect the solubilization of DNA-SWNT. To exclude the possibility that the DNA coating (functionalization) causes changes in binding affinity between the immobilized antibody and targeted protein, we carried out a binding analysis for the two types of complexes (DNA-SWNT antibody and SWNT antibody). The binding properties indicated by data for the two types of complexes clearly show that the coated DNA molecules did not interfere with the binding affinity or capacity of the immobilized antibody and target protein (Figure 6). These findings suggest that treatment with DNA improved the stability and dispersibility of SWNT in body fluid, and that DNA-SWNT could be a smart "molecular heater" vehicle for hyperthermic therapy.

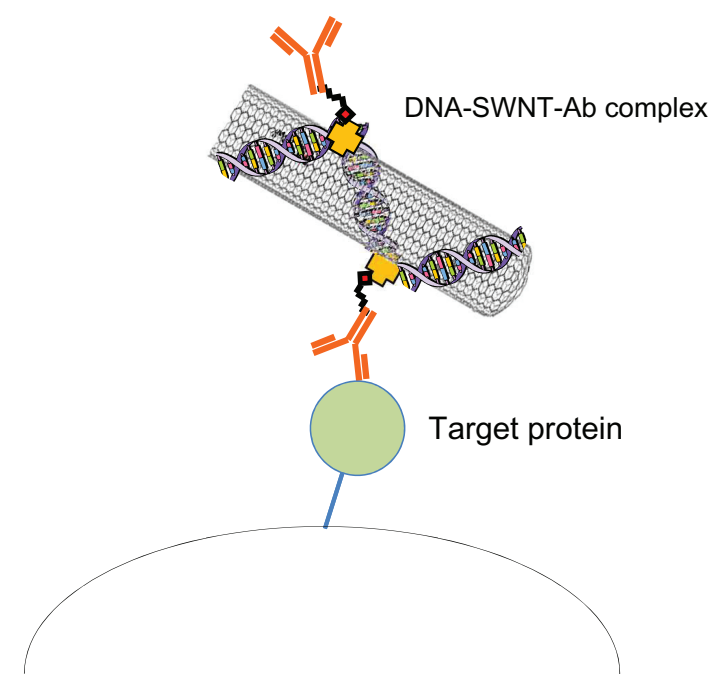

Figure 6 Schematic illustration of the DNA-SWNT antibody complex and binding to its target protein.

Abbreviations: Ab, antibody; SWNT, single-walled carbon nanotubes. 
In our previous study, we calculated the total number of carbon atoms in acid-treated SWNT as 37,000 according to the estimated value reported by Kuwahara et al (SWNT of $1.0 \mathrm{~nm}$ diameter and $660 \mathrm{~nm}$ length has 74,000 carbon atoms). ${ }^{24}$ From the QCM results for the DNA-SWNT antibody complex, we estimated that one IgG molecule attached to 21,700 carbon atoms (carbon:IgG ratio 18,900 atoms:0.87 molecules, as shown in Table 1). By assuming that the carbon atoms of the DNA-SWNT number 37,000, 1.73 molecules of IgG were immobilized on one model DNA-SWNT antibody complex system. Although there was no difference between the binding affinities of the two types of complexes (with and without DNA treatment) for the target molecule, the affinities of these complexes were lower than that of $\operatorname{IgG}$ alone. Although the reason for this difference is unclear, one possible explanation is the segmental mobility of the DNA-SWNT antibody complex. The bulky SWNT attached to the IgG molecule would affect the binding affinity of the complex for the targeted molecule.

In summary, we have demonstrated a scheme for preparing a DNA-SWNT antibody complex containing a targeting IgG moiety. The DNA-SWNT antibody complex showed good specific binding ability for the target protein. Because the complex is based on SWNT with streptavidin attached, variable biotinylated ligands corresponding to the targeted protein can be attached. The results of this study suggest that the DNA-SWNT antibody complex system is a useful and smart "molecular heater" platform applicable for various types of antibodies in response to the corresponding target molecule.

\section{Disclosure}

The authors report no conflicts of interest in this work.

\section{References}

1. Gannon CJ, Cherukuri P, Yakobson BI, et al. Carbon nanotube-enhanced thermal destruction of cancer cells in a noninvasive radiofrequency field. Cancer. 2007;110:2654-2665.

2. Klingeler R, Hampel S, Buchner B. Carbon nanotube-based biomedical agents for heating, temperature sensoring and drug delivery. Int $J$ Hyperthermia. 2008;24:496-505.

3. Liu Z, Tabakman S, Welsher K, Dai H. Carbon nanotubes in biology and medicine: in vitro and in vivo detection, imaging and drug delivery. Nano Res. 2009;2:85-120.

4. Fisher JW, Sarker S, Buchanan CF, et al. Photothermal response of human and murine cancer cells to multiwalled carbon nanotubes after laser irradiation. Cancer Res. 2010;70:1-10.

5. Madani SY, Naderi N, Dissanayake O, Tan A, Seifalian AM. A new era of cancer treatment: carbon nanotubes as drug delivery tools. Int $J$ Nanomedicine. 2011;6:2963-2979.
6. Kawaguchi M, Ohno J, Irie A, Fukushima T, Yamazaki J, Nakashima N. Dispersion stability and exothermic properties of DNA-functionalized single-walled carbon nanotubes. Int J Nanomedicine. 2011;6: 729-736.

7. Kam NWS, O'Connell M, Wisdom JA, Dai H. Carbon nanotubes as multifunctional biological transporters and near-infrared agents for selective cancer cell destruction. Proc Natl Acad Sci US A. 2005;102: 11600-11605.

8. Dhar S, Liu Z, Thomale J, Dai H, Lippard SJ. Targeted single-wall carbon nanotube-mediated $\mathrm{Pt}(\mathrm{IV})$ prodrug delivery using folate as a homing device. J Am Chem Soc. 2008;130:11467-11476.

9. Chakravarty P, Marches R, Zimmerman NS, et al. Thermal ablation of tumor cells with antibody-functionalized single-walled carbon nanotubes. Proc Natl Acad Sci U S A. 2008;105:8697-8702.

10. McDevitt MR, Chattopadhyay D, Kappel BJ, et al. Tumor targeting with antibody-functionalized radiolabeled carbon nanotubes. $\mathrm{J} \mathrm{Nucl}$ Med. 2007;48:1180-1189.

11. Marx KA. Quartz crystal microbalance: a useful tool for studying thin polymer films and complex biomolecular systems at the solution-surface interface. Biomacromolecules. 2003;4:1099-1120.

12. Furusawa H, Takano H, Okahata Y. Transient kinetic studies of $\mathrm{pH}-$ dependent hydrolyses by exo-type carboxypeptidase $\mathrm{P}$ on a $27-\mathrm{MHz}$ quartz crystal maicrobalance. Anal Chem. 2008;80:1005-1011.

13. Josephy PD, Eling T, Mason RP. The horseradish peroxidasecatalyzed oxidation of 3, 5, 3', 5' -tetramethylbenzidine. Free radical and charge-transfer complex intermediates. J Biol Chem. 1982;257: 3669-3675.

14. Park TJ, Banejee S, Hemraj-Benny T, Wong SS. Purification strategies and purity visualization techniques for single-walled carbon nanotubes. J Mater Chem. 2006;16:141-154.

15. Liu Z, Galli F, Janssen KGH, et al. Stable single-walled carbon nanotube-streptavidin complex for biorecognition. J Phys Chem. 2010;114:4345-4352.

16. Jiang K, Schadler LS, Siegel RW, Zhang X, Zhang H, Terrones M. Protein immobilization on carbon nanotubes via a two-step process of diimide-activated amidation. J Mater Chem. 2004;14:37-39.

17. Hendrickson WA, Pahler A, Smith JL, et al. Crystal structure of core streptavidin determined from multiwavelength anomalous diffraction of synchrotron radiation. Proc Natl Acad Sci U S A. 1989;86: 2190-2194.

18. Dupont-Filliard A, Billon M, Guillerez S, Bidan G. Comparison by QCM and photometric enzymatic test of the biotin-avidin recognition on a biotinylated polypyrrole. Talanta. 2001;55:981-992.

19. Erdem A, Papakonstantinou P, Murphy H, McMullan M, Karadeniz H, Sharma S. Streptavidin modified carbon nanotube based graphite electrode for label-free sequence specific DNA detection. Electroanalysis. 2010;22:611-617.

20. Balthasar S, Michaelis K, Dinauer N, von Briesen H, Kreuter J, Langer K. Preparation and characterisation of antibody modified gelatin nanoparticles as drug carrier system for uptake in lymphocytes. Biomaterials. 2005;26:2723-2732.

21. Noguchi Y, Fujigaya T, Niidome Y, Nakashima N. Single-walled carbon nanotubes/DNA hybrids in water are highly stable. Chem Phys Lett. 2008;455:249-251.

22. Nakashima N, Okuzono S, Murakami H, Nakai T, Yoshikawa K. DNA dissolves single-walled carbon nanotubes in water. Chem Lett. 2003;32: 456-457.

23. Zheng M, Jagota A, Semke ED, et al. DNA-assisted dispersion and separation of carbon nanotubes. Nat Mater. 2003;2:338-342.

24. Kuwahara S, Sugai T, Shinohara H. Determining exact molar absorbance coefficient of single-wall carbon nanotubes. Phys Chem Chem Phys. 2009;11:1091-1097. 


\section{Publish your work in this journal}

The International Journal of Nanomedicine is an international, peerreviewed journal focusing on the application of nanotechnology in diagnostics, therapeutics, and drug delivery systems throughout the biomedical field. This journal is indexed on PubMed Central, MedLine, CAS, SciSearch $\AA$, Current Contents ${ }^{\circledR} /$ Clinical Medicine,

Journal Citation Reports/Science Edition, EMBase, Scopus and the Elsevier Bibliographic databases. The manuscript management system is completely online and includes a very quick and fair peer-review system, which is all easy to use. Visit http://www.dovepress.com/ testimonials.php to read real quotes from published authors.

Submit your manuscript here: http://www.dovepress.com/international-journal-of-nanomedicine-journal 